\title{
Exceptionally hot summers in Central and Eastern Europe (1951-2010)
}

\author{
Robert Twardosz $\cdot$ Urszula Kossowska-Cezak
}

Received: 21 May 2012 / Accepted: 22 August 2012 /Published online: 6 September 2012

(C) The Author(s) 2012. This article is published with open access at Springerlink.com

\begin{abstract}
The paper focuses on exceptionally hot summers (EHS) as a manifestation of contemporary climate warming. The study identifies EHS occurrences in Central and Eastern Europe and describes the characteristic features of the region's thermal conditions. Average air temperatures in June, July and August were considered, as well as the number of days with maximum temperatures exceeding 25,30 and $35^{\circ} \mathrm{C}$, and with a minimum temperature greater than $>20^{\circ} \mathrm{C}$, as recorded at 59 weather stations in $1951-$ 2010. Extremely hot summers are defined as having an average temperature equal to or greater than the long-term average plus 2 SD. A calendar of EHSs was compiled and their spatial extent identified. The region experienced 12 EHSs, which occurred in a given year at $5 \%$ or more stations (1972, 1981, 1988, 1992, 1997, 1998, 1999, 2002, 2003, 2006, 2007 and 2010). The EHS frequency of occurrence was found to be clearly on an increase. Indeed, only one EHS occurred during the first 30 years, but these occurred five times during the last 10 years of the study period. Their geographical extent varied both in terms of location and size. EHSs were observed at 57 out of the total of 59 weather stations in the study (the exceptions were Pecora and Cluj). The average air temperature of EHSs tended to exceed the relevant long-term average by $2-4{ }^{\circ} \mathrm{C}$. The summer of 2010 was among the hottest (temperature anomaly $5.5-6{ }^{\circ} \mathrm{C}$ ) and spatially largest.
\end{abstract}

\footnotetext{
R. Twardosz $(\triangle)$

Department of Climatology, Jagiellonian University,

ul. Gronostajowa 7,

30-387 Kraków, Poland

e-mail: r.twardosz@uj.edu.pl

U. Kossowska-Cezak

Department of Climatology, Faculty of Geography and Regional

Studies, Warsaw University,

ul. Krakowskie Przedmieście 30,

00-927 Warszawa, Poland
}

\section{Introduction}

The late twentieth century and the early twenty-first century is notable in Europe for the greater frequency of exceptionally hot summer months, or even entire summer seasons. According to Della-Marta et al. (2007), the frequency of heat waves was increasing by $24 \%$ per 10 years in Western Europe. Modelling studies suggest that this rate of increase may continue in the twenty-first century producing heat waves that will not only be more frequent, but also longer and more intense (Meehl and Tebaldi 2004; Révész 2008; Kürbis et. al. 2009; Bardin 2011; Fischer and Schär 2010). This prediction is exemplified by the hot summers of 2003 and 2010, which are classified as 'mega-heatwaves' (Barriopedro et al. 2011). The occurrence of these exceptional heat waves also contributed to an increase in mortality rates in Central and Eastern Europe (Hutter et al. 2007; Muthers et al. 2010; Barriopedro et al. 2011; Revich and Shaposhnikov 2012), a region known for low rather than high temperatures having an adverse effect on human health and well-being (Błażejczyk and McGregor 2007; Twardosz 2009).

These weather anomalies are driven by a number of factors. Among the causes most frequently suggested in literature are: oceanic conditions (Black and Sutton 2007), especially their surface temperatures (Della-Marta et al. 2007; Feudale and Shukla 2011; Zveryaev et al. 2012), atmospheric circulation (Kyselý and Huth 2008; Dole et al. 2011), changes in cloudiness (Tang et al. 2012) and an increased concentration of greenhouse gases in the atmosphere (Schär et al. 2004; Stott et al. 2004; Gruza and Ran'kova 2011).

The objective of this study was twofold: (1) to determine how frequent were exceptionally hot summers (EHSs) in Central and Eastern Europe and (2) to describe the characteristics of these periods. Long-term persistence of a powerful heat stress is a characteristic of southern European climates influenced by subtropical climates. While tropical 
air masses also reach moderate latitudes, the articulated ground relief of Central Europe causes heat waves occurring in that region to be highly variable in terms of their frequency, duration, timing and intensity (Gerstengarbe and Werner 1992; Twardosz and Batko 2012). Insolation, in addition to the advection factor, is also a driving force of extreme heat waves, as the days become longer towards the summer. In Central Europe, summer temperature anomalies can exceed the long-term average by up to $3 \mathrm{SD}$, such as what occurred in 1939 (Kossowska-Cezak 1993) and 1947 (Filipiuk and Kaszewski 2000).

\section{Data and methodology}

The study is based on a body of data including, primarily, the average monthly air temperatures in summer months (June-August), as recorded at 59 selected weather stations in an area approximately defined by the geographical coordinates $45-60^{\circ} \mathrm{N}$ and $15-65^{\circ} \mathrm{E}$ (except for the Scandinavian Peninsula) in 1951-2010 (Table 1). This is supplemented by statistics including the average maximum and minimum monthly temperatures and the number of days with maximum temperatures: $>25{ }^{\circ} \mathrm{C}$ (summer days), $>30{ }^{\circ} \mathrm{C}$ (hot days) and $>35^{\circ} \mathrm{C}$ (very hot days) and with minimum temperatures $>20^{\circ} \mathrm{C}$.

The bulk of the data comes from the European Climate Assessment and Dataset (ECA\&D) (www.eca.knmi.nl). This database normally verifies all datasets for uniformity. There were gaps in the monthly average temperatures at certain Russian stations and these have been filled in using general climatological methods.

The area was divided into four belts with a width equal to $5^{\circ}$ of geographical latitude. The stations were numbered within each belt, i.e., 8 stations in the $60^{\circ} \mathrm{N}$ belt numbered 1 to 8,13 stations in belt $55-60^{\circ} \mathrm{N}$ from 9 to 21,22 stations in belt $50-55^{\circ} \mathrm{N}$ from 22 to 43 and 16 stations below $50^{\circ} \mathrm{N}$ from 44 to 59 (Table 1, Fig. 1).

Most of the weather stations are located in lowland areas, including 56 stations below 300 ma.s.l. of which 49 are below 200 ma.s.l. The only three stations with higher altitudes are: L'viv (323 m), Praha (365 m) and Cluj (413 m). Astrahan' is in a depression $(-23 \mathrm{~m})$.

Most of the study area, from its centre to the east, has a moderate continental climate, while the climate of the remaining western section is transitional between continental and maritime. The average long-term air temperature of the warmest month, i.e., July, ranges from $15{ }^{\circ} \mathrm{C}$ in the northern extremity to $25^{\circ} \mathrm{C}$ and higher in the southeast.

Exceptionally hot summers are defined as summers when the average temperature of the three summer months at a given station is higher than the long-term average of the study period (1951-2010) by at least $2 \mathrm{SD}\left(t \geq t_{\mathrm{av}}+2 \sigma\right)$.
Filipiuk and Kaszewski (2000) used a similar criterion to define hot summers in Central Europe during the period 1871-1990. The study also included the compiling of a calendar of EHSs, defining their spatial extent and describing their thermal characteristics.

\section{General characteristics of EHS occurrence}

Using the criterion adopted $\left(t \geq t_{\mathrm{av}}+2 \sigma\right)$ it was found that 15 EHSs occurred in various parts of the study area during the 60year study period. Three cases when the EHS occurred only at a single station (1954-Luhans'k, 1974-Arhangel'sk and 2000 -Beograde) are omitted in a detailed analysis provided in Section 4. Each of the remaining 12 EHSs was observed at a minimum of three stations, i.e., at $5 \%$ of the total number of stations included in the study.

During the period 1951-2010, EHS frequency varied widely. The period started with a decade (1951-1960) with only one such EHS and only at one station followed by a decade (1961-1970) without EHS. In the two subsequent decades, there were two EHSs per decade, and in the final two decades, there were five EHSs per decade. The EHSs observed during 1991-2000 covered areas represented by between one and seven stations (or 2-12\%) and those occurring during the period 2001-2010 were observed at between three stations (5\%) and 39 stations (66\%; the latter case in 2010).

A growing frequency of such extreme thermal conditions contributes to an increase in air temperature (Briffa and Osborn 2002; Jones and Moberg 2003). Indeed, Western and Southern Europe is experiencing a clear trend to a growth in summer temperature (Zveryaev and Gulev 2009). The same trend has been identified in the study area in all except its northern and eastern sections (Table 2).

Table 3 summarises years with EHSs and stations where these EHSs were observed (numbered according to Table 1).

EHSs were observed at 57 of the 59 stations and the only stations that failed to observe any such summers were Pecora (no. 7) located close to the northeastern boundary of the area and Cluj (no. 49), the highest of the stations located in an upland of central Romania. Nearly half of all stations (28) experienced two EHSs and 13 stations had three such summers. Only Riga observed five exceptionally hot summers.

\section{Location and thermal characteristics of exceptionally hot summers (EHS)}

\subsection{EHS during 1951-1980}

1972 The only EHS covering at least three stations during the first half of the 60-year study period occurred in 1972 . Observed at 16 stations, it covered vast areas of western 
Table 1 List of weather stations included in the study (station names after CLINO, WMO 1996)

\begin{tabular}{|c|c|c|c|c|c|}
\hline \multicolumn{2}{|c|}{ Station } & \multirow[t]{2}{*}{ WMO no. } & \multicolumn{2}{|c|}{ Station } & \multirow[t]{2}{*}{ WMO no. } \\
\hline No. & Name & & No. & Name & \\
\hline 1 & Vaasa & 02911 & 49 & Cluj & 15120 \\
\hline 2 & Jyväskyla & 02935 & 50 & L'viv & 33393 \\
\hline 3 & Petrozavodsk & 22820 & 51 & Chernivtsi & 33658 \\
\hline 4 & Arhangel'sk & 22550 & 52 & Bucuresti & 15420 \\
\hline 5 & Kotlas & 22887 & 53 & Chrisinau & 33815 \\
\hline 6 & Syktyvar & 23804 & 54 & Sulina & 15360 \\
\hline 7 & Pecora & 23418 & 55 & Odessa & 33837 \\
\hline 8 & Ivdel' & 23921 & 56 & Kharkiv & 34300 \\
\hline 9 & Riga & 26422 & 57 & Luhans'k & 34523 \\
\hline 10 & Tallinn & 26038 & 58 & Astrachan' & 34880 \\
\hline 11 & Daugavpils & 26544 & 59 & Atyrau & 35700 \\
\hline
\end{tabular}

Russia and some adjacent areas to the north (Fig. 1). Indeed, this exceptionally hot summer was spatially the second largest during the study period and in the northern half of the area examined it was the hottest (Table 4). During all three summer months, the average temperature was above the long-term average, but August was the hottest. In the central part of the area, this was the hottest August of the entire period. The temperature difference between the longterm average and the temperature of the particular season ranged from 2.3 to $2.7^{\circ} \mathrm{C}$ in the far north, to $3.6-3.9^{\circ} \mathrm{C}$ in the far south, to $4.5^{\circ} \mathrm{C}$ at Tambov $\left(t \geq t_{\mathrm{av}}+3 \sigma\right)$. Days with a temperature higher than $30{ }^{\circ} \mathrm{C}$ were recorded even in the north, where they were very rare in other years, while in the south there were 50 such days (two to three times more than the average). In the south, there were also days with a maximum temperature greater than $35^{\circ} \mathrm{C}$. Throughout the area there were cases of hot nights, i.e., 24-hdays with a minimum temperature higher than $20{ }^{\circ} \mathrm{C}$, including for example six such days in Arhangel'sk (compared to 0.4 on average) and 17 in Voronez (normally 2.6).

These unusual thermal anomalies in western Russia were caused by a quasi-stationary anticyclonic circulation (Bardin 2007). Recent research (Zveryaev et al. 2012) shows that the summer of 1972 was characterised by the positive phase of the North Atlantic Oscillation.

\subsection{EHS during 1981-1990}

1981 The exceptional summer of this year covered the central and eastern parts of European Russia (Fig. 2). The EHS was observed at eight stations, including the easternmost Ivdel' (where it was the only such summer during the period) and Ekaterinburg. In Kirov and Perm, this was the hottest summer of the period. The average air temperature across the area was higher than the long-term average by $2.5-3.3{ }^{\circ} \mathrm{C}$. The 


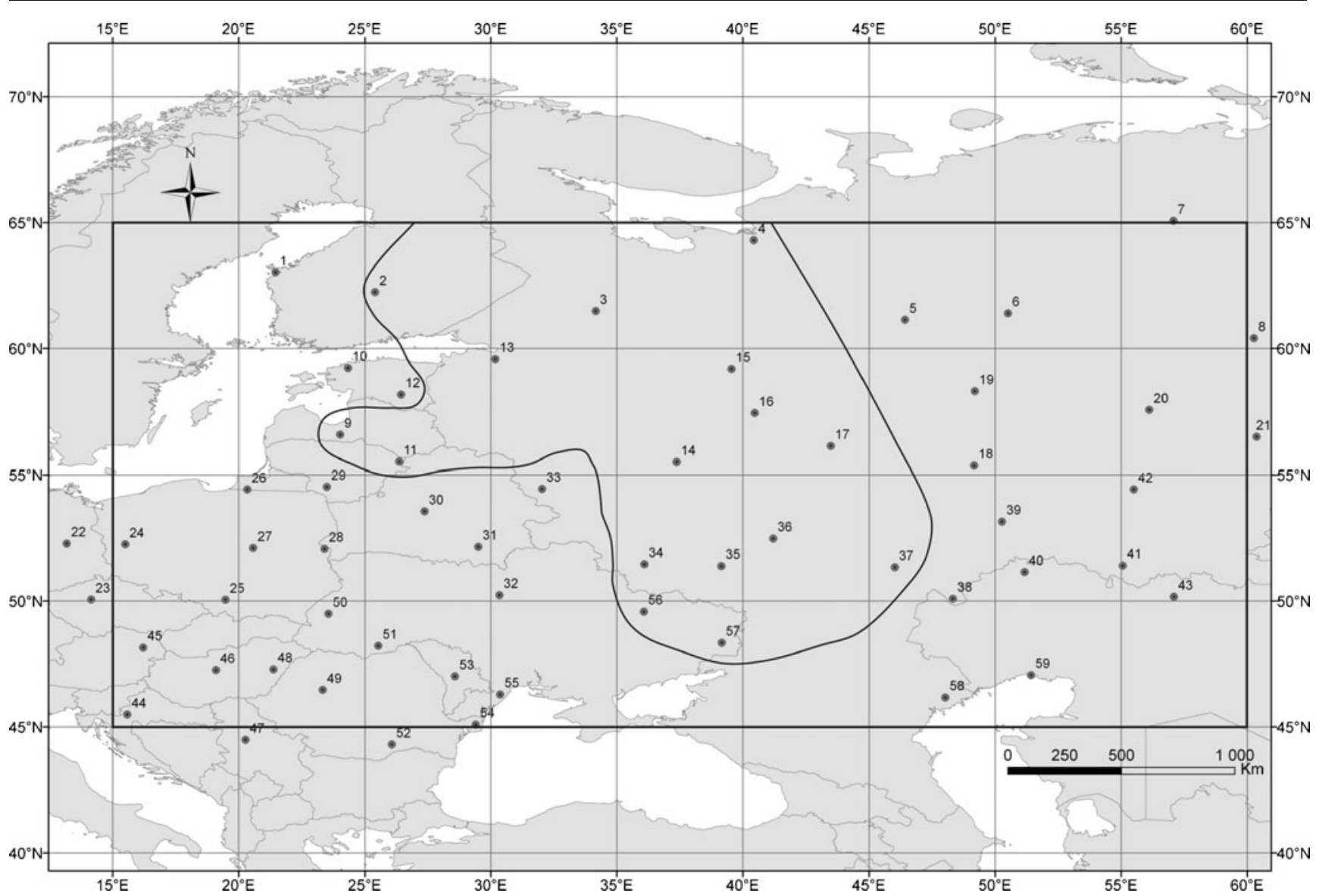

Fig. 1 Spatial coverage of the exceptionally hot summer of 1972. For station numbers, consult Table 1

temperature was higher than the long-term average in all three summer months, but August was the only exceptionally hot month and only at half of all the stations (including the hottest of the whole period in Ivdel', Ekaterinburg and Perm), while June and July did not meet the criterion. There was a considerable number of days with a maximum temperature higher than $30^{\circ} \mathrm{C}$, especially in the south $(20-25$, on average 9-11).
Only in the southwestern part of the area, there were days with minimum temperatures exceeding $20^{\circ} \mathrm{C}$ (Table 5).

1988 The summer of 1988 was exceptionally hot and, as in 1981, air temperature anomalies covered central and eastern parts of European Russia, although the affected area was smaller involving only five stations (Fig. 2). In three

Table 2 Time trend of the summer average temperature as described by linear regression on time (1951-2010)

“_" $\alpha>0.05 ; * \alpha=0.05-0.01$;

$* * \alpha=0.01-0.001 ; * * * \alpha<0.001$

\begin{tabular}{llllll}
\hline Station & & $R^{2}$ & $\begin{array}{l}\text { Regression coefficient } \\
\left({ }^{\circ} \mathrm{C} / 100 \text { year }\right)\end{array}$ & $p$ value & Significance \\
\cline { 1 - 2 } No. & Name & & & & \\
\hline 2 & Jyväskyla & 0.05 & $+1.3 \pm 0.8$ & 0.086 & - \\
7 & Pecora & 0.000 & $-0.01 \pm 1.0$ & 0.99 & - \\
14 & Moskva & 0.035 & $+1.4 \pm 1.0$ & 0.14 & - \\
20 & Perm & 0.001 & $+0.2 \pm 0.9$ & 0.81 & - \\
27 & Warszawa & 0.08 & $+1.7 \pm 0.7$ & 0.025 & $*$ \\
41 & Orenburg & 0.004 & $+0.5 \pm 1.0$ & 0.61 & - \\
45 & Wien & 0.37 & $+\mathbf{3 . 4} \pm 0.6$ & 0.000 & $* *$ \\
55 & Odessa & 0.13 & $+\mathbf{2 . 5} \pm 0.8$ & 0.0038 & $* *$ \\
56 & Kharkiv & 0.021 & $+1.2 \pm 1.1$ & 0.26 & - \\
59 & Atyrau & 0.12 & $+\mathbf{2 . 4} \pm 0.8$ & 0.005 & $* *$ \\
\hline
\end{tabular}


Table 3 Exceptionally hot summers (EHS) in Central and Eastern Europe (1951-2010)
Station numbers printed in bold mean that the average summer temperature at that station met the formula $t \geq t_{\mathrm{av}}+3 \sigma$. A number in brackets means that the station had no single month in the category in that year

\begin{tabular}{llll}
\hline Year & $\begin{array}{l}\text { Number of } \\
\text { stations }\end{array}$ & Stations (numbers as in Table 1) & Exceptionally hot months \\
\hline 1972 & 16 & $2,3,4,(9),(11), 13,14,15,16,17$, & August \\
1981 & 8 & $34,35, \mathbf{3 6}, 37,56,57$ & \\
1988 & 5 & $(6), 8,(17),(18), 19,20,21,(42)$ & August at some stations \\
1992 & 7 & $5,6,19,20,(21)$ & July \\
1997 & 3 & $22,24,25,27,45,46,48$ & August \\
1998 & 3 & $(1),(2), 9$ & August at Riga \\
1999 & 3 & $40,41,43$ & June \\
2002 & 10 & $9,30,53$ & June \\
2003 & 7 & $1,2,9,(11), 24,26,28,29,30,50$ & July and August \\
2006 & 3 & $22,23, \mathbf{4 4}, \mathbf{4 5}, 46,47,(48)$ & June and August \\
2007 & 8 & $(10), 24,27$ & July \\
& & $45,46,47,48,(51), 52, \mathbf{5 3}, 55$ & June; in south, July; in east, \\
2010 & 39 & $3,9,10,11, \mathbf{1 2}, 13, \mathbf{1 4}, 15,16, \mathbf{1 7}, \mathbf{1 8}$, & August \\
& & $19,26,(27), 28,29, \mathbf{3 0}, \mathbf{3 1}, \mathbf{3 2}, \mathbf{3 3}, \mathbf{3 4}$, & July and August throughout \\
& & $\mathbf{3 5}, \mathbf{3 6}, \mathbf{3 7}, \mathbf{3 8}, \mathbf{3 9}, \mathbf{4 0}, 41,42, \mathbf{4 3}, 50$, & \\
& & $51,53,54,55, \mathbf{5 6}, 57, \mathbf{5 8}, \mathbf{5 9}$ & \\
\hline
\end{tabular}

northern stations, this was the hottest, and in the case of Kotlas, also the only EHS in the study period. The difference between the average long-term and the EHS average temperature ranged from 2.3 to $3.1{ }^{\circ} \mathrm{C}$ across the area. July proved particularly hot (at some stations the hottest of the period). Only in Ekaterinburg did the temperatures stop short of meeting the criteria in any of the months. There were more than 10 days with a maximum temperature above $30^{\circ} \mathrm{C}$ at all the stations, and in the south, the number was nearly 20 (compared to between three and six on average). Only isolated instances of days with a minimum temperature above $20{ }^{\circ} \mathrm{C}$ were recorded in the south of the area affected (Table 5).

\subsection{EHS during 1991-2000}

1992 This was the first case in the second half of the twentieth century of an EHS in a small western part of the area (7 stations,
Fig. 2). In southern Poland and in Berlin, this was the hottest summer of the study period. During the entire summer, the average temperature exceeded the long-term average by 2.0 $2.7^{\circ} \mathrm{C}$, but the greatest difference was in Krakow. August was particularly hot and in this month, the coverage of the hot area extended beyond the EHS area into the east and south. In these areas, this was the hottest August of the study period. In Krakow, where the summer of 1992 was the only EHS during the study period, the temperature difference in August reached $4.3{ }^{\circ} \mathrm{C}\left(t \geq t_{\mathrm{av}}+3 \sigma\right)$. Kossowska-Cezak (1993) demonstrated that a similar heat stress had previously occurred in August 1939 and also pointed out that there had been a particularly strong temperature anomaly across southern Poland which could be attributed in part to a major wild fire which at that time was located about $120 \mathrm{~km}$ west of Krakow.

This latter conjecture is substantiated by a record high number of days with a maximum temperature exceeding
Table 4 Thermal characteristics of the summer of 1972

${ }^{\mathrm{a}}$ Highest in 60 years

\begin{tabular}{|c|c|c|c|c|c|c|c|c|}
\hline \multicolumn{2}{|c|}{ Station } & \multirow{2}{*}{\multicolumn{3}{|c|}{ Temperature $\left({ }^{\circ} \mathrm{C}\right)$}} & \multicolumn{4}{|c|}{ No. of days with temperature } \\
\hline \multirow[t]{2}{*}{ No. } & \multirow[t]{2}{*}{ Name } & & & & \multicolumn{3}{|l|}{$T_{\max }$} & \multirow{2}{*}{$\begin{array}{l}T_{\min } \\
>20^{\circ} \mathrm{C}\end{array}$} \\
\hline & & Average & Maximum & Minimum & $>25{ }^{\circ} \mathrm{C}$ & $>30{ }^{\circ} \mathrm{C}$ & $>35{ }^{\circ} \mathrm{C}$ & \\
\hline 4 & Archangel'sk & $16.8^{\mathrm{a}}$ & $22.8^{\mathrm{a}}$ & 11.1 & $35^{\mathrm{a}}$ & $11^{\mathrm{a}}$ & - & 6 \\
\hline 9 & Riga & 18.8 & 23.5 & 14.1 & 39 & 1 & - & - \\
\hline 13 & St. Petersburg & $20.1^{\mathrm{a}}$ & $24.9^{\mathrm{a}}$ & 15.8 & $50^{\mathrm{a}}$ & 16 & - & 14 \\
\hline 14 & Moskva & 20.7 & 26.4 & 14.7 & 58 & 24 & - & 6 \\
\hline 17 & Niznij Novgorod & 20.9 & 25.5 & 15.6 & 52 & 17 & - & 19 \\
\hline 35 & Voronez & 23.5 & 29.9 & 17.3 & 75 & 47 & 8 & 17 \\
\hline 56 & Kharkiv & 23.2 & 29.0 & 17.3 & 75 & 43 & 3 & 14 \\
\hline
\end{tabular}




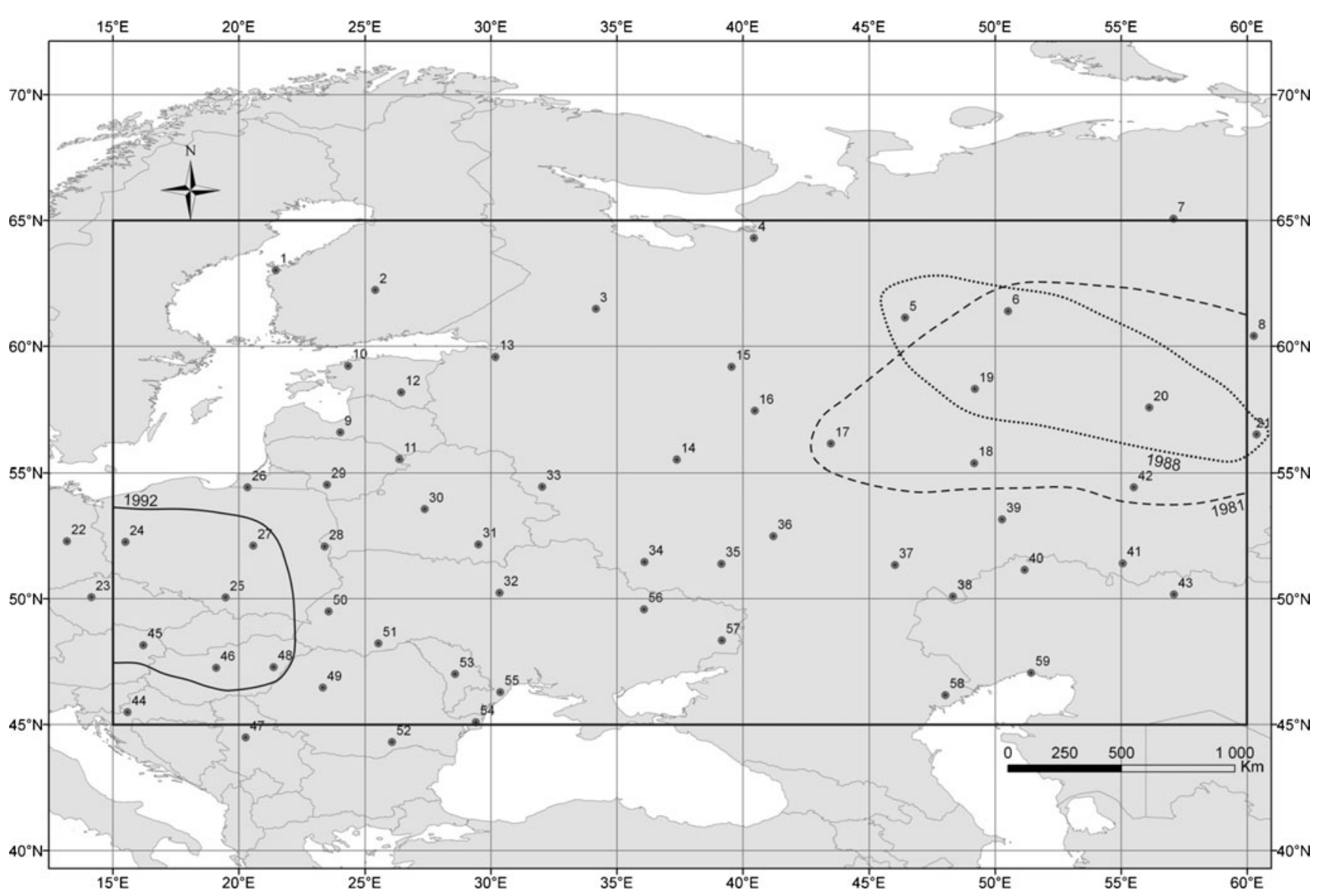

Fig. 2 Spatial coverage of the exceptionally hot summer of 1981, 1988 and 1992

$35{ }^{\circ} \mathrm{C}$ (13 compared to the average of 0.4 , while in Warszawa it was 3 compared to the average of 0.2 ). In a southern section of the area affected there were more than 10 days with a minimum temperature higher than $20{ }^{\circ} \mathrm{C}$ (Table 6). At that time, Central Europe was dominated by a long-term circulation from the southwest (KossowskaCezak 1993) linked to an anticyclonic wedge from the
Azores within which a secondary high-pressure system developed over the Balkans. This pressure distribution pattern caused an advection of tropical air. While this effect developed, a foehn wind contributed to the temperature increase in southern Poland (Kuziemska 1987). Heat waves were also observed in Central Europe in other years in similar weather conditions (Fink et al. 2004). It is worth noting that
Table 5 Thermal characteristics of the summer of 1981 and 1988

${ }^{\mathrm{a}}$ Highest in 60 years

\begin{tabular}{|c|c|c|c|c|c|c|c|c|}
\hline \multicolumn{2}{|c|}{ Station } & \multirow{2}{*}{\multicolumn{3}{|c|}{ Temperature $\left({ }^{\circ} \mathrm{C}\right)$}} & \multicolumn{4}{|c|}{ No. of days with temperature } \\
\hline \multirow[t]{2}{*}{ No. } & \multirow[t]{2}{*}{ Name } & & & & \multicolumn{3}{|l|}{$T_{\max }$} & \multirow{2}{*}{$\begin{array}{l}T_{\min } \\
>20^{\circ} \mathrm{C}\end{array}$} \\
\hline & & Average & Maximum & Minimum & $>25{ }^{\circ} \mathrm{C}$ & $>30{ }^{\circ} \mathrm{C}$ & $>35{ }^{\circ} \mathrm{C}$ & \\
\hline \multicolumn{9}{|c|}{1981} \\
\hline 17 & Niznij Novgorod & 20.5 & 27.6 & 15.7 & $72^{\mathrm{a}}$ & 29 & - & 10 \\
\hline 20 & Perm & $19.7^{\mathrm{a}}$ & $26.4^{\mathrm{a}}$ & $13.6^{\mathrm{a}}$ & $63^{\mathrm{a}}$ & 18 & - & - \\
\hline 21 & Ekaterinburg & 19.8 & 26.2 & 14.4 & $64^{\mathrm{a}}$ & 12 & - & - \\
\hline \multicolumn{9}{|c|}{1988} \\
\hline 5 & Kotlas & $17.8^{\mathrm{a}}$ & $24.0^{\mathrm{a}}$ & $12.0^{\mathrm{a}}$ & 41 & 13 & - & - \\
\hline 20 & Perm & 19.4 & 25.7 & 13.4 & 50 & $21^{\mathrm{a}}$ & - & 1 \\
\hline 21 & Ekaterinburg & $20.0^{\mathrm{a}}$ & $26.4^{\mathrm{a}}$ & 14.5 & 53 & 19 & - & 2 \\
\hline
\end{tabular}


Table 6 Thermal characteristics of the summer of 1992, 1997, 1998 and 1999

\section{${ }^{\mathrm{a}}$ Highest in 60 years}

${ }^{\mathrm{b}}$ All days in August

\begin{tabular}{|c|c|c|c|c|c|c|c|c|}
\hline \multicolumn{2}{|c|}{ Station } & \multirow{2}{*}{\multicolumn{3}{|c|}{ Temperature $\left({ }^{\circ} \mathrm{C}\right)$}} & \multicolumn{4}{|c|}{ No. of days with temperature } \\
\hline \multirow[t]{2}{*}{ No. } & \multirow[t]{2}{*}{ Name } & & & & \multicolumn{3}{|l|}{$T_{\max }$} & \multirow{2}{*}{$\begin{array}{l}T_{\min } \\
>20^{\circ} \mathrm{C}\end{array}$} \\
\hline & & Average & Maximum & Minimum & $>25{ }^{\circ} \mathrm{C}$ & $>30{ }^{\circ} \mathrm{C}$ & $>35{ }^{\circ} \mathrm{C}$ & \\
\hline \multicolumn{9}{|c|}{1992} \\
\hline 22 & Berlin & $20.0^{\mathrm{a}}$ & $25.9^{\mathrm{a}}$ & $14.2^{\mathrm{a}}$ & $53^{\mathrm{a}}$ & 14 & 2 & 1 \\
\hline 25 & Krakow & $20.1^{\mathrm{a}}$ & $27.6^{\mathrm{a}}$ & 14.2 & $65^{\mathrm{a}}$ & 22 & $13^{\mathrm{a}, \mathrm{b}}$ & 1 \\
\hline 45 & Wien & 22.1 & 27.5 & 16.7 & 65 & 28 & 3 & $10^{\mathrm{a}}$ \\
\hline \multicolumn{9}{|c|}{1997} \\
\hline 2 & Jyvaskyla & 16.7 & $22.6^{\mathrm{a}}$ & 10.2 & 29 & - & - & - \\
\hline 9 & Riga & 19.0 & $23.8^{\mathrm{a}}$ & $14.2^{\mathrm{a}}$ & 40 & 5 & - & 2 \\
\hline \multicolumn{9}{|c|}{1998} \\
\hline 41 & Orenburg & 24.0 & 31.0 & 16.7 & 81 & 55 & 24 & $22^{\mathrm{a}}$ \\
\hline \multicolumn{9}{|c|}{1999} \\
\hline 9 & Riga & 18.8 & 22.8 & 10.5 & 33 & 6 & - & - \\
\hline 30 & Minsk & 20.0 & $25.7^{\mathrm{a}}$ & 14.5 & 50 & 9 & - & - \\
\hline
\end{tabular}

heat waves depend not only on the direction of advection of air masses, but also on whether the situation is cyclonic or anticyclonic (Kossowska-Cezak 1997).

1997 This exceptionally hot summer was observed at only three stations in the northwestern extremity of the region (Vaasa, Jyväskyla and Riga). The only individual month that reached that category was August in Riga. The average temperature of the summer exceeded the long-term average by $2.1-2.4{ }^{\circ} \mathrm{C}$. The average maximum temperature was particularly high (the highest in the study period), while in the northern stations there was also a large number of days with a maximum temperature higher than $25^{\circ} \mathrm{C}$ (30-40 days compared to 12-17 days on average, Table 6).

1998 The EHS of 1998 covered only a small southeastern corner of the area, including three stations (Ural'sk, Orenburg and Aktobe). The difference between the average temperature of the EHS and the long-term average ranged from 2.9 to $3.2{ }^{\circ} \mathrm{C}$. June stood out with its high temperatures, although all months had temperatures higher than the long-term average. This exceptionally hot June, the hottest in the study period, was observed from Samara to the Caspian Sea and it stood out with a very high frequency of the hottest days, i.e., with a maximum temperature above $35^{\circ} \mathrm{C}$ and a minimum temperature above $20^{\circ} \mathrm{C}$, that is four times more than the long-term average (Table 6).

1999 The EHS covered a vast area of western Russia, Belarus and the Ukraine (with an extremely hot June), but the seasonal average temperature only met the criterion at three stations located far apart from each other (Riga, Minsk and Chisinau), where the temperature difference compared to the long-term average was $2.2-2.9^{\circ} \mathrm{C}$ (Table 6). Three other stations, i.e., St. Petersburg, Smolensk and Odessa, fell marginally short (by just $0.1^{\circ} \mathrm{C}$ ), of meeting the criterion $t \geq t_{\mathrm{av}}+2 \sigma$.

This summer event featured a large number of days with a maximum temperature above $25^{\circ} \mathrm{C}$ (33-50, compared to the average of $12-24)$ and above $30^{\circ} \mathrm{C}$ (6-9 vs. 2).

\subsection{EHS during 2001-2010}

2002 The summer was exceptionally hot in western parts of the study area covering two specific areas: southern Finland (two stations) and an area spanning Lithuania, Latvia, a part of Poland, Belarus and the Ukraine (ten stations) (Fig. 3). This was the hottest summer of the study period in Riga, Kaliningrad and at the Finnish stations.

The EHS was warmer than the long-term average by $1.9^{\circ} \mathrm{C}$ in the south and $2.6-2.8^{\circ} \mathrm{C}$ in the north of the area. Two of the months proved exceptionally hot, each in a different area: July in Minsk and L'viv (as well as across vast areas up to Moscow and on the Black Sea coast); and August in the larger central and northern section of the area (the hottest month at certain of the stations). Days with a maximum temperature above $30{ }^{\circ} \mathrm{C}$ did not occur in Finland at all, but about 10 such days were recorded in central and southern stations (as compared to the average of 2-3 days); the number of days with a maximum temperature above $25{ }^{\circ} \mathrm{C}$ was twice the norm. Cases of days with a minimum temperature above $20^{\circ} \mathrm{C}$ were either isolated or not recorded at all (Table 7).

2003 This was a summer of heatwaves in Western Europe, especially in August, and has been researched by numerous authors (e.g., Hitzesommer 2003; Fink et al. 2004; Schär et al. 2004; Stott et al. 2004; Chase et al. 2006; Rebetez et al. 


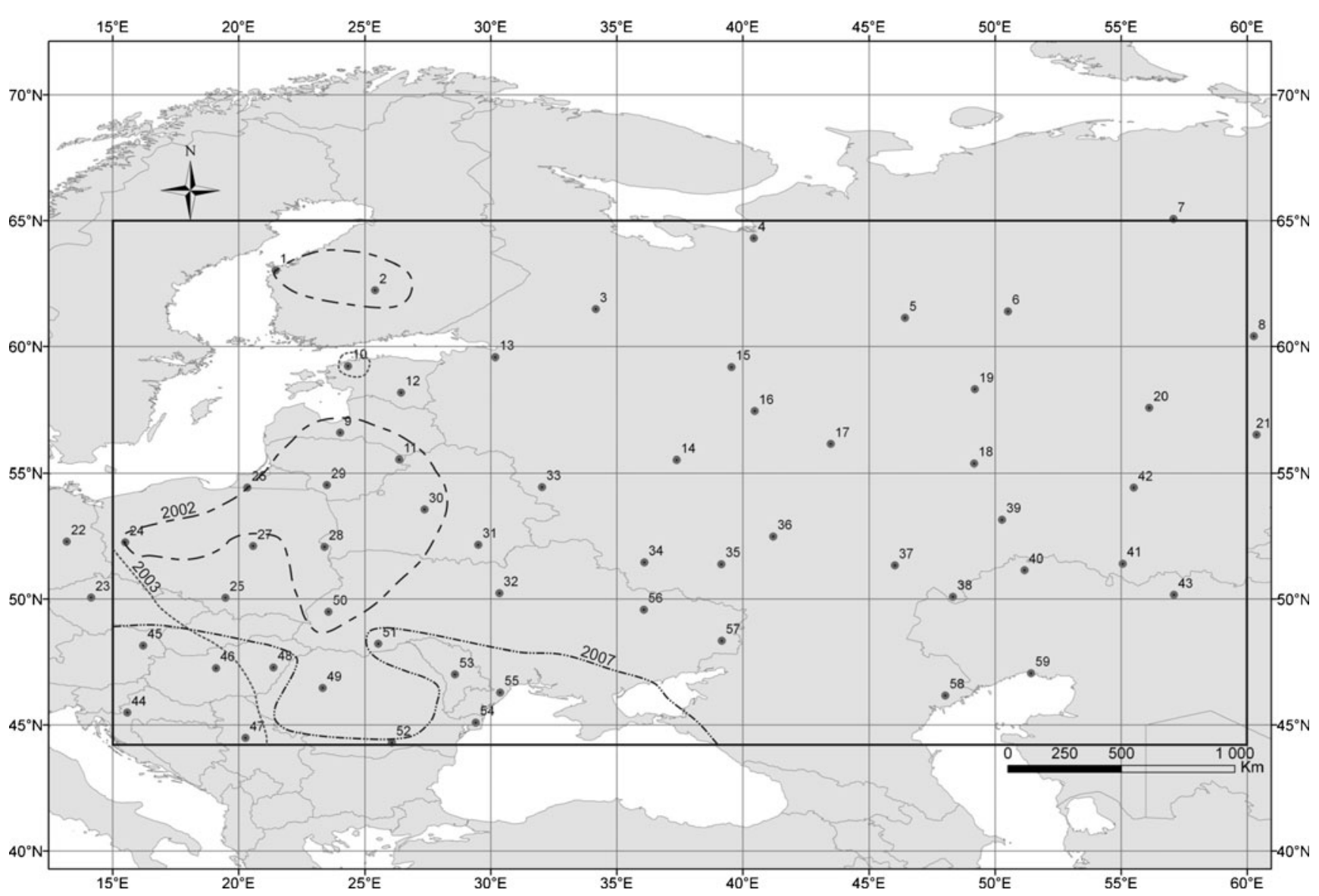

Fig. 3 Spatial coverage of the exceptionally hot summer of 2002, 2003 and 2007

2009; D'Ippoliti et al. 2010; Twardosz 2009; Twardosz and Batko 2012). In August, the highest measured anomaly was
$+6.9{ }^{\circ} \mathrm{C}$, at the southwestern rim of the Massif Central (station Gourdon) in France (Friedrich and Bissolli 2012).
Table 7 Thermal characteristics of the summer of 2002, 2003, 2006 and 2007

${ }^{\text {a}}$ Highest in 60 years, a value in bold means that the temperature meets the criterion $t \geq t_{\mathrm{av}}+3 \sigma$

\begin{tabular}{|c|c|c|c|c|c|c|c|c|}
\hline \multicolumn{2}{|c|}{ Station } & \multirow{2}{*}{\multicolumn{3}{|c|}{ Temperature $\left({ }^{\circ} \mathrm{C}\right)$}} & \multicolumn{4}{|c|}{ No. of days with temperature } \\
\hline \multirow[t]{2}{*}{ No } & \multirow[t]{2}{*}{ Name } & & & & \multicolumn{3}{|l|}{$T_{\max }$} & \multirow{2}{*}{$\begin{array}{l}T_{\min } \\
>20^{\circ} \mathrm{C}\end{array}$} \\
\hline & & Average & Maximum & Minimum & $>25{ }^{\circ} \mathrm{C}$ & $>30{ }^{\circ} \mathrm{C}$ & $>35^{\circ} \mathrm{C}$ & \\
\hline \multicolumn{9}{|c|}{2002} \\
\hline 2 & Jyvaskyla & 16.8 & $22.6^{\mathrm{a}}$ & 11.0 & 24 & - & - & - \\
\hline 9 & Riga & $19.4^{\mathrm{a}}$ & 23.5 & 11.9 & $50 ?$ & $8 ?$ & - & $4 ?$ \\
\hline 30 & Minsk & 19.6 & 25.3 & 14.2 & 47 & 11 & - & 3 \\
\hline 50 & L'viv & 19.1 & $25.0^{\mathrm{a}}$ & 13.7 & 47 & 7 & - & 1 \\
\hline \multicolumn{9}{|c|}{2003} \\
\hline 22 & Berlin & $20.0^{\mathrm{a}}$ & $25.9^{\mathrm{a}}$ & 14.1 & 49 & 18 & - & - \\
\hline 45 & Wien & $23.0^{\mathrm{a}}$ & $28.8^{\mathrm{a}}$ & $17.2^{\mathrm{a}}$ & $76^{\mathrm{a}}$ & $37^{\mathrm{a}}$ & 3 & $10^{\mathrm{a}}$ \\
\hline 47 & Beograd & $24.6^{\mathrm{a}}$ & $30.5^{\mathrm{a}}$ & $18.9^{\mathrm{a}}$ & $84^{\mathrm{a}}$ & 51 & 8 & 29 \\
\hline \multicolumn{9}{|c|}{2006} \\
\hline 27 & Warszawa & 19.9 & 25.6 & 14.1 & $47^{\mathrm{a}}$ & $22^{\mathrm{a}}$ & 1 & 2 \\
\hline \multicolumn{9}{|c|}{2007} \\
\hline 45 & Wien & 21.7 & 27.3 & 15.9 & 68 & 20 & 4 & 6 \\
\hline 47 & Beograd & $24.6^{\mathrm{a}}$ & $30.5^{\mathrm{a}}$ & 18.6 & 79 & 45 & $16^{\mathrm{a}}$ & 29 \\
\hline 55 & Odessa & $24.4^{\mathrm{a}}$ & 28.2 & $19.9^{\mathrm{a}}$ & $86^{\mathrm{a}}$ & 31 & 6 & 41 \\
\hline
\end{tabular}


The heatwaves reached only the southwestern edge of the study area (Fig. 3). At all seven stations where they were recorded, this was the hottest summer of the study period (Table 7) with the anomaly ranging from $+2.3{ }^{\circ} \mathrm{C}$ in Berlin to $3.6^{\circ} \mathrm{C}$ in Zagreb. At Praha and Zagreb, this was the only EHS of the 60-year period and the anomaly reached more than 3 SD at Zagreb and Wien. The temperatures considerably exceeded the long-term average in all 3 months, but only June and August were exceptionally hot. June proved the hottest of the study period while August was the hottest only at certain stations. During these months, the anomaly was $+3.5-4.5^{\circ} \mathrm{C}$. The EHS featured a high number of days with a maximum temperature above $30^{\circ} \mathrm{C}$, especially in the south (15 on average and more than half of all such days in the summer). There were days with a maximum temperature above $35{ }^{\circ} \mathrm{C}$ (except Berlin) and in Zagreb and Beograd there were frequent hot nights (up to 40 days and 10-11 on average with a minimum temperature above $20^{\circ} \mathrm{C}$; Table 7).

This exceptional heat wave was partly accounted for by a very stable meteorological situation which became 'blocked in' and dominated most of the continent (Fink et al. 2004; Twardosz 2009). An analysis of a Met Office synoptic map of Europe revealed that a powerful high-pressure system had developed over Scandinavia and a wedge of this reached into Central Europe. This system imposed a circulation that pulled hot tropical air into Western Europe from the south.

2006 This year, the summer was exceptionally hot at only three stations: Tallinn (Estonia), Warszawa and Poznan (Central Poland). The temperature met the criterion adopted $\left(t \geq t_{\mathrm{av}}+2 \sigma\right)$ and the anomaly equalled $+2.1-2.4{ }^{\circ} \mathrm{C}$. In Poland, July was exceptionally hot (the hottest during the study period), but in Tallinn no month qualified in this category. In Poland, the summer of 2006 stood out with the highest frequency of days with a maximum temperature above $30{ }^{\circ} \mathrm{C}$ (more than 20 vs. 5 on average) during the period (Table 7). During that summer, there was also one of the longest heatwaves on record in Poland (KossowskaCezak 2010; Krzyżewska and Wereski 2011), as well as in Prague (Kyselý 2010).

2007 This summer was exceptionally hot on the southwestern edge of the area from Slovakia to Hungary to the Black Sea lowland, but excluding inland Romania and the Danube delta (eight stations, Fig. 3). In most of the stations (excluding Wien and Budapest), this was the hottest summer, and in Bucuresti, it was the only EHS of the entire study period. The temperature anomaly ranged from $1.9{ }^{\circ} \mathrm{C}$ in the west to $3.1^{\circ} \mathrm{C}$ in the east and to $3.5^{\circ} \mathrm{C}$ at Chisinau $\left(t \geq t_{\mathrm{av}}+3 \sigma\right)$. In the area affected, June was everywhere exceptionally hot (in Bucuresti, Chisinau and Odessa it was the hottest of the period), July was particularly hot in Beograd, Bucuresti and Chisinau (also the hottest in the study period) and August in Odessa. The maximum temperature often exceeded $30^{\circ} \mathrm{C}$ in southern parts of the area (in Bucuresti on 68 days vs. an average of 34 days) and even $35^{\circ} \mathrm{C}$ (in Beograd 16 vs. 3 days; in Bucuresti 20 vs. 4 , which was the highest in the study period). Hot nights occurred across the area, but particularly frequently in Odessa (41 vs. 17; Table 7). The most intense heatwaves, however, were recorded outside of the study area, especially in Greece (Founda and Giannakopoulos 2009).

2010 The EHS of 2010 was absolutely exceptional in the study period: it covered the largest geographical area and in most of the places affected it was not just the hottest, but also extremely different from the average conditions with the high temperatures lasting for a particularly long period (Fig. 4, Table 8).

The EHS conditions covered most of European Russia (excluding its northern and eastern extremities) and territories to the west of it, including the Gulf of Finland and Gulf of Riga, eastern Poland, the Ukraine and the northeastern tip of Romania (Fig. 4). The EHS criterion was met at 39 of all 59 stations, including 32 stations where it was the hottest summer and 9 stations where it was the only EHS of the study period. The temperature anomaly ranged from $+2.2-$ $2.7^{\circ} \mathrm{C}$ in the north and west to $3.5-4.5^{\circ} \mathrm{C}$ on the Caspian Sea and $5.5-6.0^{\circ} \mathrm{C}$ at the centre of the area. According to a study by Wehry (2010), the area of the temperature anomaly exceeding $5.0^{\circ} \mathrm{C}$ was seven times as large as the area of the same anomaly value in August 2003. At 18 stations in the central part of the area, from Minsk and Kyiv in the west to Ufa in the east and from Moscow and Kazan' in the north to Kharkiv and the Caspian coast in the south, the air temperature exceeded the long-term average by $3 \mathrm{SD}$ and the highest anomaly, recorded at Kursk, was $4 \sigma, 6.0^{\circ} \mathrm{C}$.

July and August were exceptionally hot in nearly the entire area and almost everywhere they were the hottest during the study period. June was also exceptionally hot in an area from Kyiv to Voronez and in southern Kazakhstan. While during previous EHSs it was rare for 2 months to qualify for this category within a single summer, in 2010 this situation was recorded at 21 stations. Additionally, at six stations (Kyiv, Kursk, Voronez, Kharkiv, Astrahan' and Atyrau) all 3 months were exceptionally hot. Warszawa was an exception, as none of the months cleared the threshold conditions of the exceptionally hot month category despite this summer being one of two of the city's hottest summers during the study period and a full EHS (Table 8).

Days with a maximum temperature above $30^{\circ} \mathrm{C}$ occurred over the whole area and ranged from 15-20 days in the north and west (compared to an average 2-3 days) to 5060 days in the centre and the east $(10-20)$ to more than 80 days in the far southeast (50-60). On the Caspian coast on almost every day the maximum temperature was higher than $30{ }^{\circ} \mathrm{C}$ and only 5 days fell short of it (87 days vs. 


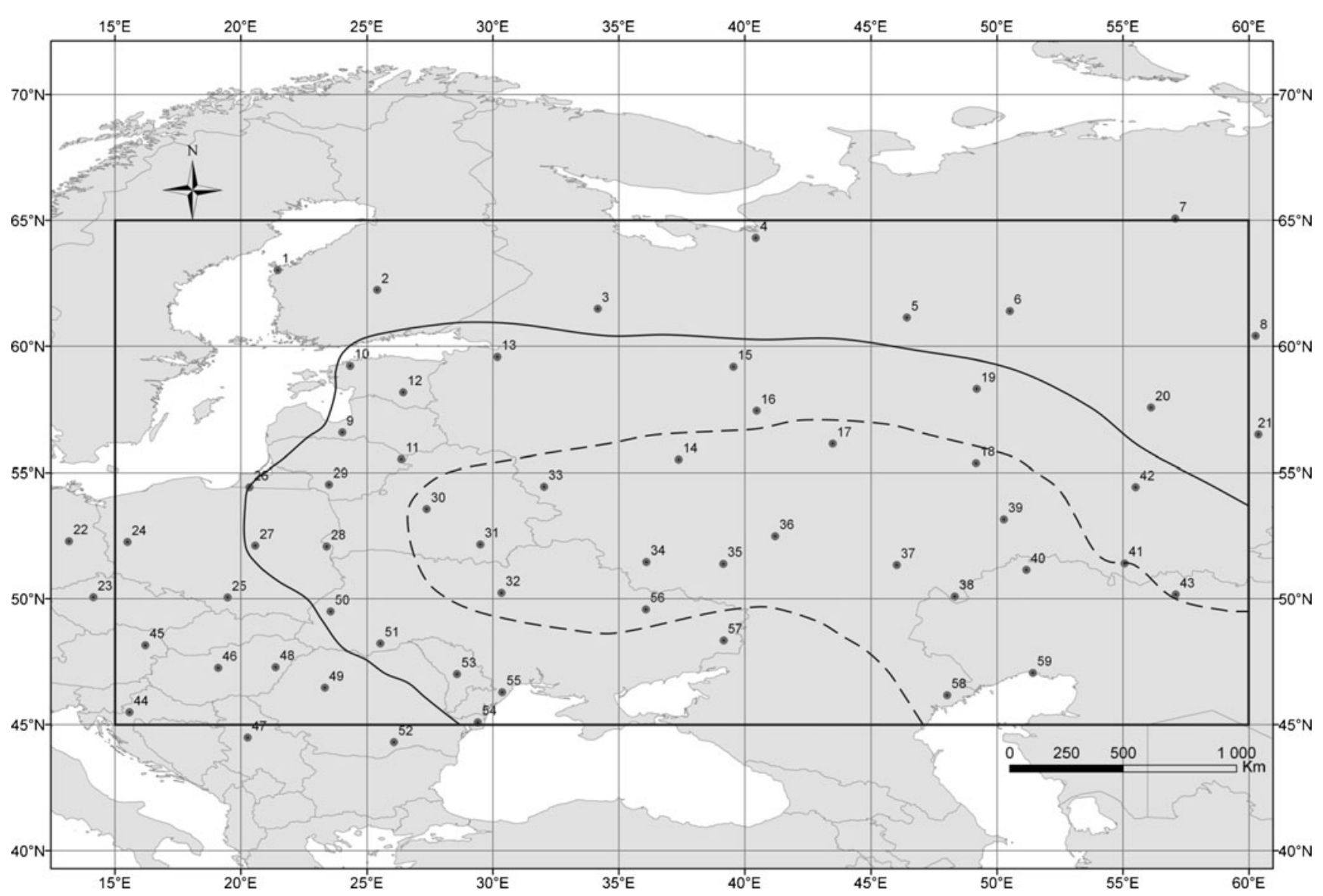

Fig. 4 Spatial coverage of the exceptionally hot summer of 2010; dashed line marks the area with an anomaly greater or equal to 3 SD

60 days on average); on 59 days the temperature exceeded $35{ }^{\circ} \mathrm{C}$ (20 days on average). The only section of the area without days with a maximum temperature above $35^{\circ} \mathrm{C}$ was the far west. Two such days even occurred in St. Petersburg, for the first time in the study period, and elsewhere the numbers ranged from 20 in the centre of the area to 40 days
Table 8 Thermal characteristics of the summer of 2010

${ }^{\text {a}}$ Highest in 60 years, a value in bold means that the temperature meets the criterion $t \geq t_{\mathrm{av}}+3 \sigma$

\begin{tabular}{|c|c|c|c|c|c|c|c|c|}
\hline \multicolumn{2}{|c|}{ Station } & \multirow{2}{*}{\multicolumn{3}{|c|}{ Temperature $\left({ }^{\circ} \mathrm{C}\right)$}} & \multicolumn{4}{|c|}{ No. of days with temperature } \\
\hline \multirow[t]{2}{*}{ No. } & \multirow[t]{2}{*}{ Name } & & & & \multicolumn{3}{|l|}{$T_{\max }$} & \multirow{2}{*}{$\begin{array}{l}T_{\min } \\
>20^{\circ} \mathrm{C}\end{array}$} \\
\hline & & Average & Maximum & Minimum & $>25^{\circ} \mathrm{C}$ & $>30^{\circ} \mathrm{C}$ & $>35^{\circ} \mathrm{C}$ & \\
\hline 9 & Riga & 18.8 & 23.5 & 10.1 & 36 & $15^{\mathrm{a}}$ & - & $13 ?$ \\
\hline 13 & St. Petersburg & 19.9 & 23.8 & $16.0^{\mathrm{a}}$ & 43 & $19^{\mathrm{a}}$ & $2^{\mathrm{a}}$ & $22^{\mathrm{a}}$ \\
\hline 14 & Moskva & $21.9^{\mathrm{a}}$ & $27.8^{\mathrm{a}}$ & $16.0^{\mathrm{a}}$ & $64^{\mathrm{a}}$ & $44^{\mathrm{a}}$ & $16^{\mathrm{a}}$ & $24^{\mathrm{a}}$ \\
\hline 18 & Kazan' & $23.3^{\mathrm{a}}$ & $31.2^{\mathrm{a}}$ & 15.5 & $78^{\mathrm{a}}$ & $57^{\mathrm{a}}$ & $34^{\mathrm{a}}$ & $22^{\mathrm{a}}$ \\
\hline 27 & Warszawa & $20.0^{\mathrm{a}}$ & 24.9 & $15.0^{\mathrm{a}}$ & 45 & 17 & - & $6^{\mathrm{a}}$ \\
\hline 32 & Kyiv & $24.0^{\mathrm{a}}$ & $29.6^{\mathrm{a}}$ & $18.4^{\mathrm{a}}$ & $76^{\mathrm{a}}$ & $44^{\mathrm{a}}$ & $14^{\mathrm{a}}$ & $34^{\mathrm{a}}$ \\
\hline 34 & Kursk & $24.4^{\mathrm{a}}$ & $30.2^{\mathrm{a}}$ & $18.7^{\mathrm{a}}$ & $75^{\mathrm{a}}$ & $51^{\mathrm{a}}$ & $21^{\mathrm{a}}$ & $41^{\mathrm{a}}$ \\
\hline 35 & Voronez & $24.8^{\mathrm{a}}$ & $31.0^{\mathrm{a}}$ & $18.1^{\mathrm{a}}$ & $77^{\mathrm{a}}$ & $55^{\mathrm{a}}$ & $23^{\mathrm{a}}$ & $32^{\mathrm{a}}$ \\
\hline 39 & Samara & $25.0^{\mathrm{a}}$ & $31.2^{\mathrm{a}}$ & 15.5 & $78^{\mathrm{a}}$ & $57^{\mathrm{a}}$ & $34^{\mathrm{a}}$ & 22 \\
\hline 41 & Orenburg & $24.8^{\mathrm{a}}$ & $32.6^{\mathrm{a}}$ & $16.9^{\mathrm{a}}$ & $83^{\mathrm{a}}$ & $66^{\mathrm{a}}$ & $40^{\mathrm{a}}$ & 21 \\
\hline 50 & L'viv & $19.6^{\mathrm{a}}$ & 24.6 & $14.5^{\mathrm{a}}$ & 46 & 16 & - & 1 \\
\hline 55 & Odessa & $24.4^{\mathrm{a}}$ & $28.6^{\mathrm{a}}$ & 19.6 & 74 & 30 & $7^{\mathrm{a}}$ & $47^{\mathrm{a}}$ \\
\hline 59 & Atyrau & $29.4^{\mathrm{a}}$ & $35.8^{\mathrm{a}}$ & $25.5^{\mathrm{a}}$ & 90 & $87^{\mathrm{a}}$ & $59^{\mathrm{a}}$ & $75^{\mathrm{a}}$ \\
\hline
\end{tabular}


in Orenburg (on average 1-2 and 6 days in Orenburg) to 60 days on the Caspian coast (20 on average). Hot nights $\left(t_{\min }>20^{\circ} \mathrm{C}\right)$ occurred throughout the area: at most stations the numbers ranged from 20 to 40 nights (compared to two to three on average in general and five to seven in the east), but in the south they exceeded 40: 47 in Odessa, 48 in Kharkiv, 56 Astrahan' and 75 in Atyrau (compared to the long-term average 17, 4, 26 and 32). This means that even in the warmest areas, where hot nights tend to be quite frequent and occur every year, they were at least twice as numerous in the summer of 2010.

Highly adverse and tangible economic effects, for example extensive wildfires, accompanied the extremely hot and long summer of 2010, especially in Russia and the Ukraine. These fires increased air pollution around Moscow by a factor of 2-3 (Zvyagintsev et al. 2011), which in turn contributed to the development of extremely burdensome biothermal conditions and increased mortality rates. This posed the question about the contribution of the fires to the extreme thermal conditions in the central part of European Russia. Very high temperatures can contribute to the starting and spreading of wildfires, but the huge quantities of heat produced in wildfires can stimulate further temperature growth in a positive feedback loop. It is conceivable that the heat from the burning of an enormous mass of wood compensated for the reduced solar radiation received at surface level caused by clouds of smoke blocking out the sun. This is confirmed by research covering the hot summer of 1992 in Poland (Kossowska-Cezak 1993).

The occurrence of these exceptional heatwaves in 2010 was linked with a persistent ridge of high pressure, initially related to the Azores high, but subsequently strengthened by a strong advection of warm air from the Middle East (WMO 2010). The strong high-pressure ridge over Russia created a highly stable and 'blocking' weather situation, which forced an air mass advection from the south (Masters 2010; Gruza and Ran'kova 2011).

\section{Conclusions}

Based on a precise statistical criterion (an average temperature higher or equal to a relevant long-term average plus 2 SD), all exceptionally hot months and summers (EHS) during the 60-year study period (1951-2010) were identified at 59 weather stations in Central and Eastern Europe. The study focused on whole seasons.

There were 12 EHS that occurred at a minimum of $5 \%$ of stations in the same year $(1972,1981,1988,1992,1997$, 1998, 1999, 2002, 2003, 2006, 2007 and 2010). Their frequency was clearly on a rise, as the numbers increased from a single EHS occurrence during the first 30 years of the period to five events in the last decade.

A greater frequency of extremely hot conditions contributed to higher summer air temperatures in the western and southern sections of the study area. No such temperature increases were found in the northern and eastern sections due to a lower frequency or lack of EHSs.

These exceptionally hot summers varied in their location and the extent of the areas they covered. An EHS occurred once during the study period at 15 stations (a majority of stations in 2010), twice at 28 stations, three times at 13 stations and five times in Riga. The only areas where such EHSs did not occur at all were the extreme northeast of the area (represented by Pechora) and high altitudes (represented by Cluj, the highest located station in the study at $413 \mathrm{~m}$ ).

The average air temperature of exceptionally hot summers tended to exceed the relevant long-term average by $2-4{ }^{\circ} \mathrm{C}$. Greater anomalies than this were recorded only in 1972, 2003 and 2010, in which last year the maximum anomaly value of $+5.5-6{ }^{\circ} \mathrm{C}$ was also recorded. In all the exceptionally hot summers all the months had above-average temperatures and there was usually also at least one exceptionally hot month, although there were some EHSs without such exceptionally hot months. The first EHSs with two exceptionally hot months occurred only in the $21 \mathrm{st} \mathrm{c}$. and the first EHS with all 3 months being exceptionally hot occurred in 2010 .

The heat wave of the summer of 2010 was the hottest, had the largest geographical extent, highest anomaly value and longest duration. It should be regarded as an extreme climatic phenomenon due to its exceptionally adverse biometerological conditions and serious economic impacts, including vast wild fires.

The increase in the frequency of occurrence of exceptionally hot summers might be easily attributed to the global warming, but the phenomenon seems to be more complex than that, with other factors, including the changing territory where it occurs, also operating. The results of this study are not sufficient to predict whether the phenomenon may increase in the future or whether it is just an episode in the long-term temperature profile of Central and Eastern Europe.

Acknowledgments We thank Mr. Paweł Pilch and Dr. Martin Cahn for reviewing the English.

Open Access This article is distributed under the terms of the Creative Commons Attribution License which permits any use, distribution, and reproduction in any medium, provided the original author(s) and the source are credited.

\section{References}

Bardin MY (2007) Anticyclonic quasi-stationary circulation and its effect on air temperature anomalies and extremes over western Russia. Russ Meteorol Hydrol 32(2):75-84

Bardin MY (2011) Scenary forecasts of air temperature variations for the regions of the Russian Federation up to 2030 using the empirical stochastic climate models. Russ Meteorol Hydrol 36(4):217-228

Barriopedro D, Fischer EM, Luterbacher J, Trigo RM, García-Herrera R (2011) The Hot Summer of 2010: redrawing the temperature record map of Europe. Science 332(6026):220-224 
Black E, Sutton R (2007) The influence of oceanic conditions on the hot European summer of 2003. Clim Dyn 28:53-66

Błażejczyk K, McGregor G (2007) Warunki biotermiczne a umieralność w wybranych aglomeracjach europejskich. Prz Geograficzny 34:401-423

Briffa KR, Osborn TJ (2002) Blowing hot and cold. Science 295 (5563):2227-2228

Chase TN, Wolter RA, Pielke SR, Rasool I (2006) Was the 2003 European summer heat wave unusual in a global context? Geophys Res Lett 33:L23709

Della-Marta PM, Luterbacher J, von Weissenfluh H, Xoplaki E, Brunet M, Wanner H (2007) Summer heat waves over Western Europe 1880-2003, their relationship to large-scale forcings and predictability. Clim Dyn 29:251-275

D'Ippoliti D, Michelozzi P, Marino C, de'Donato F, Menne B, Katsouyanni K, Kirchmayer U, Analitis A, Medina-Ramón M, Paldy A, Atkinson R, Kovats S, Bisanti L, Schneider A, Lefranc A, Iniguez C, Perucci CA (2010) The impact of heat waves on mortality in 9 European cities: results from the EuroHEAT project. Environ Heal 9(37):1-9

Dole R, Hoerling M, Perlwitz J, Eischeid J, Pegion P, Zhang T, Quan XW, $\mathrm{Xu}$ T, Murray D (2011) Was there a basis for anticipating the 2010 Russian heat wave? Geophys Res Lett 38:L06702. doi:10.1029/ 2010GL046582

Feudale L, Shukla J (2011) Influence of sea surface temperature on the European heat wave of 2003 summer. Part I: an observational study. Clim Dyn 36(9-10):1691-1703

Filipiuk E, Kaszewski BM (2000) Hot and cold summer in Central Europe (1871-1990). Prace Geograficzne 108:149-154

Fink AH, Brücher T, Krüger A, Leckebusch GC, Pinto JG, Ulbrich U (2004) The 2003 European summer heatwaves and drought-synoptic diagnosis and impacts. Weather 59 (8):209-216

Fischer EM, Schär C (2010) Consistent geographical patterns of changes in high-impact European heat waves. Nat Geosci 3:398-403

Founda D, Giannakopoulos C (2009) The exceptionally hot summer of 2007 in Athens, Greece - a typical summer in the future climate? Glob Planet Chang 67(3-4):227-236

Friedrich K, Bissolli P (2012) Analysis of Temperatures and Precipitation recorded at stations in Eastern Europe during the heat wave in summer 2010. Deutscher Wetterdienst, Business Area Climate and Environment. http://www.dwd.de/bvbw/generator/DWDWWW/ Content/Oeffentlichkeit/KU/KU2/KU23/rcc-cm/products/SWE/ European/20110124 Hitzewelle Russland de,templateId=raw, property=publicationFile.pdf/20110124_Hitzewelle_Russland de.pdf. Accessed 09 February 2011

Gerstengarbe FW, Werner PC (1992) The time structure of extreme summers in Central Europe between 1901 and 1980. Meteorol Z NF 1:285-289

Gruza GV, Ran'kova EY (2011) Estimation of probable contribution of global warming to the genesis of abnormally hot summers in the European part of Russia. Izv Atmos Ocean Phys 47(6):661-664

Auswirkungen des Hitzesommer 2003 auf die Gewässer (2004) Dokumentation. Schriftenreiche Umwelt, Nr 369. Gewässerschutz, Bern

Hutter HP, Moshammer H, Wallner P, Leitner B, Kundi M (2007) Heatwaves in Vienna: effects on mortality. Wien Klin Wochenschr 119(7-8):223-227

Jones PD, Moberg A (2003) Hemispheric and large-scale surface air temperature variations: an extensive revision and an update to 2001. J Clim 16:206-223

Kossowska-Cezak U (1993) Lato roku 1992 w Polsce na tle sezonów letnich ostatnich 120 lat. Prz Geofizyczny 1:67-74

Kossowska-Cezak U (1997) Miesieczne warunki termiczno-opadowe i ich zależność od cyrkulacji atmosferycznej. Pr i Stud Geograficzne $20: 125-144$
Kossowska-Cezak U (2010) Występowanie pogody gorącej w Warszawie (1951-2009). Prz Geofizyczny 1-2:61-75

Krzyżewska A, Wereski S (2011) Fale upałów i mrozów w wybranych stacjach Polski na tle regionów bioklimatycznych (2000-2010). Prz Geofizyczny 1-2:99-109

Kürbis K, Mudelsee M, Tetzlaff G, Brázdil R (2009) Trends in extremes of temperature, dew point, and precipitation from long instrumental series from Central Europe. Theor Appl Climatol 98:187-195

Kuziemska D (1987) Zróżnicowanie temperatury powietrza na obszarze Polski a typy cyrkulacji atmosferycznej nad Europa Środkowa. Prz Geofizyczny 3:277-287

Kyselý J (2010) Recent severe heat waves in Central Europe: how to view them in a long-term prospect? Int J Climatol 30:89-109

Kyselý J, Huth R (2008) Relationships of surface air temperature anomalies over Europe to persistence of atmospheric circulation patterns conducive to heat waves. Adv Geosci 14:243-249

Masters J (2010) Causes of the Russian heat wave and Pakistani floods. http://www.wunderground.com/blog/JeffMasters/comment.html? entrynum $=1576$. Accessed on 9 February 2011

Meehl GA, Tebaldi C (2004) More intense, more frequent, and longer lasting heat waves in the 21st century. Science 305:994-997

Muthers S, Matzarakis A, Koch E (2010) Climate Change and Mortality in Vienna - a human biometeorological analysis based on regional climate modeling. Int J Environ Res Publ Health 7:2965-2977

Rebetez M, Dupont O, Giroud M (2009) An analysis of the July 2006 heatwave extent in Europe compared to the record year of 2003. Theor Appl Climatol 95:1-7

Révész A (2008) Stochastic behaviour of heat waves and temperature in Hungary. Appl Ecol Environ Res 6(4):85-100

Revich BA, Shaposhnikov DA (2012) Climate change, heat waves, and cold spells as risk factors for increased mortality in some regions of Russia. Stud Russ Econ Dev 23(2):195-207

Schär C, Vidale PL, Lüthi D, Frei C, Häberli C, Liniger MA, Appenzeller C (2004) The role of increasing temperature variability in European summer heatwaves. Nature 427:332-336

Stott DA, Stone DA, Allen MR (2004) Human contribution to the European heatwave of 2003. Nature 432:610-614

Tang Q, Leng G, Groisman PY (2012) European hot summers associated with a reduction of cloudiness. J Clim, http://dx.doi.org/ 10.1175/JCLI-D-12-00040.1

Twardosz R (2009) Fale niezwykłych upałów w Europie na początku XXI wieku. Prz Geofizyczny 3-4:193-204

Twardosz R, Batko A (2012) Heat waves in Central Europe (19912006). International Journal of Global Warming. (in press)

Wehry W (2010) Der heiße Sommer 2010 in Russland-Teil 2: Meteorologische Ursachen der Waldbrände. Beitr. Berliner Wetterkarte 52/10 (SO 24/10).

WMO (1996) Climatological Normals (CLINO) for the period 19611990. Geneva, 1996, WMO

WMO (2010) Current extreme weather events. http://www.wmo.int/ pages/mediacentre/news/extremeweathersequence_en.html Accessed 9 February 2011

Zveryaev I, Gulev SK (2009) Seasonality in secular changes and interannual variability of European air temperature during the twentieth century. J Geophys Res 114:D02110. doi:10.1029/ 2008JD010624

Zveryaev I, Zyulyaeva Yu, Gulev S, Koltermann P (2012) Intercomparison of the Russian summer heatwaves of 2010 and 1972. Geophysical Research Abstracts, Vol. 14, EGU2012-9714, 2012, EGU General Assembly 2012

Zvyagintsev AM, Blum OB, Glazkova AA, Kotel'nikov SN, Kuznetsova IN, Lapchenko VA, Lezina EA, Miller EA, Milyaev VA, Popikov AP (2011) Air pollution over European Russia and Ukraine under the hot summer conditions of 2010. Izvestiya, Atmos Ocean Phys 47(6):699-707 